\title{
The Implementation of Self-Assessment in EFL Writing Classroom: An Experimental Study
}

\author{
Hussein Meihami ${ }^{1, *}$, Zeinab Varmaghani ${ }^{2}$ \\ 1Department of English Language Teaching, Ghorveh Branch, Islamic Azad University, Ghorm-yran \\ 2BA Student of Primary Education, Ghorveh Branch, Islamic Azad University, Gho seh, Iran \\ *E-mail address: hussein.meihami@yahoo.com

\section{ABSTRACT} \\ Writing skill is an essential requirement to lifelong learn
} feedback for their students on writing is quite challengin instruction is Self Assessment. Self-assessment methods is writ to promote student writing achievement through refle on and metacognition during the writing process. This paper describes the findings of an investiga on using elf assessment in EFL writing classroom. For the purpose of conducting this research, 48 in intermediate students, all male and with age range of 20 to 23 , were chosen to $p$ inate in this investigation. These participants were divided into two equal groups: an experimental roup a1) who worked on their writings through self assessment and a control group ( $\mathrm{N}=24)$ who $\mathrm{w} \mathrm{r}$. d on eir writings based on the traditional ways. It was found that participants in the ey ental gr up significantly improved their writing proficiency means score, whereas improveme in th control $g$ was not significant. The results confirm that self assessment is successful witi

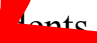

Keywords: EFL writing cl room; elf A ssment; upper intermediate students; writing skill instruction

\section{INTROP CTIO}

ucatio instutions have taken advantage of multi-media technologies to develop ney and hi ovative odes of language learning, distance and independent learning programs hav oy to of to learning opportunities for people who would otherwise not be able to partici in regular classes (Kristen Nielsen, 2012). In distance education, students are physically cant from the teacher (and, often, each other) but are nevertheless in contact; in independer learning, students study independently without the aid of a teacher and without the collegial support of other learners.

Assessment in teacher-led distance language programs tends to be addressed in much the same way as in classroom-based learning, in that some exercises may be self-marked by learners, others may be subject to peer-feedback or assessment, and yet others are submitted to the course teacher for assessment (Diltz, J. 2006). Assessment in independent learning programs, whether stand-alone courses or self-access supplements to class teaching, is more 
problematic; in the absence of a teacher or other students, the onus is placed upon learners themselves to monitor and assess their own progress and achievement.

Traditional approaches to the self-assessment of language ability are of two main types: (i) objectively-marked discrete-point tests of linguistic knowledge, and (ii) rating scales or checklists (Brindley, 1989; North, 2000; Oscarson, 1989). Objectively tests, although reliable as self-assessment instruments, do not allow learners the opportunity to produce a complex or sustained piece of written or oral communicative performance, one of the objectives of outcomes-based learning. They tend to focus either on the more traditional 'building blocks' of language learning (grammar and vocabulary) or on language comprehension (the ronative skills, reading and listening). Such assessment, while it allows learners to checl where ir linguistic knowledge or understanding might be lacking, does not allow them valuate th ability to put their newly-acquired linguistic resources to use in sus'aine roducti performance.

Rating scales and checklists, in contrast, tend to be based on sit tional script is ("I can express ...," "I can write ..."); and whilst they focus on situate " an require immediate performance (Kristen Nielsen, 2012). They t ad to be tivel unreliable as they not only require learners to make their own interpre a of standì , but are also dependent on the learner having had direct experience of th partio situation (Ross, 1998). Such self-assessments tend not to be linked to specin a w orses or hing but are more commonly used to estimate proficiency levels in general terms fo/placement purposes (Brindley, 1989).

Neither of these traditional approaches to self- essment, lthough valuable and useful across a range of assessment contexts, al how for thessment of actual productive (written or spoken) performance by learners. the potential for "fruitful development of self-evaluated language learning" afforded by ney w Mogies (Oscarson, 1989, p. 10), there appears to be no precedent for learner self-asse ment of specific task-based performance.

Perhaps because the asse sme of prod ctive skills is considered to be a "highlysubjective and complex dom (Hj kela \& Person, 2000, p. 113), it is typically seen as beyond the reach of les rs tiscrvon Where self-assessment of actual productive performance does occu it is either the context of reflection on and selection of work for portfolios, which typ all kes place y thin teacher-led courses and is guided to a large extent by a teacher (Hiry la \& Piel 2000) and focuses more on process than outcome (Porter \& Cleland, 1995/ or, where it 1 /more autonomous activity, the focus is typically on the identificatio gra zatical efrors in written texts produced by learners rather than on the overall qualitio the text earners are provided with marking codes which present them with sample vmat erros, so that they can mark their work themselves, but which tend not to focy on hore co municatively oriented criteria such as content or sociolinguistic app. ria tov/ structure and organization, or coherence.

lack of an autonomous approach to the evaluation of one's own task-based text productio $\%$ therefore, problematic for communicatively-oriented independent learning programs where the aim is to develop in learners the ability to produce communicatively effective pieces of written or spoken text; because as Kristen Nielsen (2012) said there is no teacher to provide feedback on the quality of their written production, learners need to be able to do it themselves with a degree of accuracy if they are to establish a valid sense of their own learning and progress. In an independent learning program which is based on communicative principles, if learners are not able to obtain this feedback, they may also be less motivated to complete the tasks (Warne, B.M., 2008). 


\section{1. Literature Review}

Over the past 20 years, self assessment has been increasingly used in a range of education settings. According to Blanche and Merino (1989), the first reports on self assessment were published in 1976. Since then, self assessment has continued to expand as a distinct field of study in L2 learning and education. Self assessment and other self-reflective activities usually require learners to grade their peers or their own performance, based on clearly defined task requirements and assessment criteria that are sometimes derived from the learners' input. The types of self assessment described in the literature are varied. They range from standardized questionnaires (e.g., AlFalley, 2004; Bachman \& Palmer, 1989; Patri, 2002; Stefar to open-ended, informal activities, e.g., reflective diaries and portfolios (e.g., $C$ stteral, 20 Donato \& McCormick, 1994).

In the field of education and second language acquisition (SLA), assessment is usually understood as an alternative means to assess learn ' $\mathrm{s}^{\prime}$ ab 'ity. As alt,

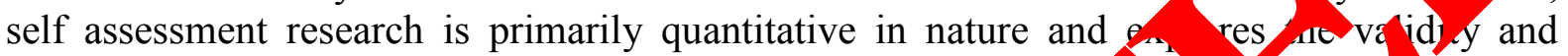
reliability of student self-ratings (e.g., AlFalley, 2004; Bachmar _Pà r. 1989 Blanche, 1990; Boud, 1995; Boud \& Tyree, 1995; Butler \& Lee, 2006 ierce, Swa \& Hart, 1993) rather than the learning process involved in self-appraisal act itic esearch o estions usually revolve around two main themes, which can be summari us follo (1) Is self assessment a reliable tool for assessing performance? (2) Wha are the variab likely to affect the reliability of scores, and how can these variable be controlled? The reliability of self assessment is usually measured by correlating the se assessed pe formance score with that of the instructor or other external benchmarks (e.g., stan dized to sts).

Variables affecting self assessment a macy are nuse, ranging from the domain of assessment to item construction and the learn is m dual attributes such as personality traits, affectivity, and level of proficiency (Bachm, \& Pal ner, 1989; Blanche \& Merino, 1989; Butler \& Lee, 2006; Ross, 1998) findin s suggest that self assessment procedures are too subjective to be used for mma e asses ent purposes, particularly in environments where the stakes are high.

However, the const act of se sessment in the SLA literature is currently shifting away from issues strictly cop ing assess $/$ theory to embrace a broader view of self assessment as a tool for motiva $\mathrm{g}$ an phancing learning. Indeed, a renewed interest in self-reflective practices is curr my emergh in models and research on motivation and autonomy (e.g., Noels, Cle'm nt, \& Pelletier, s99; Noels, Pelletier, Cle'ment, \& Vallerand, 2000), as it appears that tra ${ }_{\text {STH }} \mathcal{C}$ some of the learning responsibilities from the instructor to the learner increase grner $\mathrm{n}$ stivation. Self assessment is a means by which such a transfer can take $\mathrm{san}$ it $\mathrm{p}_{\mathrm{a}} \mathrm{s}$ an opportunity for learners to become increasingly self-regulated. $\mathrm{No}$ et (1999) suggested that feedback, self-reflection, motivation, and autonomy are inten agoing, dynamic fashion, a sort of "work in progress" for the duration of a course.

They so found in a subsequent study (Noels et al., 2000) that in an autonomy-supportive environment, students were less likely to feel anxious in the learning process and less likely to give up L2 learning. Thus self assessment provides a suitable interface between feedback, selfreflection, and increased autonomous learning, enabling both learner and instructor to reflect on the learning process and to give or receive mutual feed-back (Cotteral, 2000; Noels et al., 1999; Tremblay \& Gardner, 1995).

Anxiety was long ago identified as a major impediment to learning, particularly in its effects on learners' self-efficacy. Tremblay and Gardner (1995) described self-efficacy as the learner's perceived ability (or expectancy) to meet the challenge of language learning in 
relation to specific tasks and suggested that anxiety is a "debilitating component of selfefficacy"' (p. 508). In other words, self-efficacy and language anxiety are conceptually related but in an opposite direction, and for learning to take place, anxiety levels need to be lowered and self-efficacy boosted. Research has shown a consistent moderate negative relationship between language anxiety and achievement (Gardner, Tremblay, \& Masgoret, 1997; Horwitz et al., 1986; MacIntyre, Noels, \& Cle'ment, 1997), and a number of studies have shown that speaking is the most likely skill to be associated with foreign language anxiety (e.g., Horwitz et al., 1986; Young, 1986, 1990).

Anxiety in the L2 is associated with deficits in listening comprehension, imnaired vocabulary learning, reduced word production, and low grades in the language cov se (Gan r et al., 1997), and Horwitz (2001) suggested that anxious language le ers tend underestimate their abilities. Interestingly, some recent research by Mills, Prares d Herr $(2006,2007)$ suggested that it is students' self-efficacy beliefs, rather an anxiet, hat re closely related to academic performance.

Clearly, instructors need to help learners develop greater self on (sel ifficacy) and thereby reduce their language learning anxiety. Tremblay ad Gardn 1995, suggested that instructors should encourage learners to set appropriate so because aviduals with specific and challenging goals persist longer at a task than ndivi $/ \mathrm{s}$ with easy and vague goals" (p. 508). Mills et al. (2006) suggested encou ugno learners adopt planning and monitoring strategies in order to foster a more proacti e positive linguis $\mathrm{c}$ behavior. Both goalsetting and proactive use of strategies enable learner $b$ attribute s ccess or failure to their own level of effort and strategy use, rather than factors vide their control such as luck or task difficulty. This ability empowers learnep and hel $\mathrm{p}$ develop a greater sense of achievement (Graham, 2004).

Self assessment seems to be a tool well- lite wing learners to develop appropriate goals and self-regulate or monitor their effor accordingly (Warne, B.M., 2008). From this perspective, self-reflective activi aes s, ald not considered the end point of the process (i.e., self-reporting of past perfor ce), as they are traditionally defined in self assessment

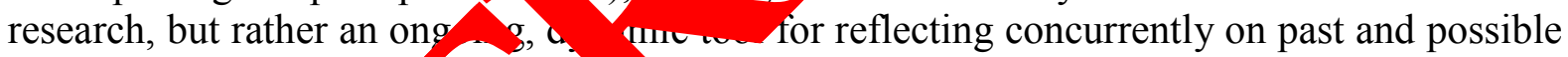
future performance and rrning beh or,

This view of le nen active a ents in their own learning is also proposed in sociocultural theory (S T), Lant and Thorne (2006) discussed the critical notion of agency in learning. They described age $/$ as the ability of individuals to assign relevance and significance thing and events (p. 143). This ability is thought to be influenced by the learners' own rical tra ctory, learning goals, and developmental stage.

Th ore lea rs a able to exercise agency, the more they become autonomous, selfregy ated irners (1 1ey, 2003). In line with this paradigm, Ushioda (2003) argued that the mo. tio lom is not solely located within the individual but is also socially distributed, and the socral unit of the classroom is instrumental in developing and sustaining the motivatio findividual learners.

Ushiosa suggested that if learners perceive the learning environment as supportive rather than inhibiting, their self-confidence and motivation to interact in the classroom will grow accordingly. 


\section{METHODOLOGY}

\section{1. Research Question}

Does using self assessment in EFL writing classroom improve learners writing ability.

\section{2. Research Hypothesis}

The implementation of self assessment has no effect of improving EFL learners writing ability.

\section{3. Participant}

A total of 94 accounting students of Azad University, Ghorveh Branch Tra male w age range of 20 to 24 were recruited voluntarily to participate in an En glish Ess Writ $\mathrm{ng}$ Program (EERP), a free credit course. Prior to the program students to $\mathrm{k}$ a pi ficiens st in English Essay Writing. According to the obtained scores, 22 sa no rank d as pre intermediate, 13 students ranked as intermediate, 48 students ranl ca as up intern diate, and 10 students ranked as advanced level of proficiency in Englis 1 ay Writin. this research we selected the 48 upper intermediate students to investige the st of this research. They were divided into an experimental group $(\mathrm{N}=28)$ an control oun $(\mathrm{N}=28)$. In the experimental group the principles and theories of self Issessment in Eng ash essay writing were practiced. In the control group, however, the teac er assessment method in English essay writing was practiced. The duration of the program as about $\mathrm{t}$ ro months, sixteen sessions. There were two sessions in each week. Two Englis av witing teachers were called to participate in this program. The experiment self assessment in their classroom, while the eac control group was required to use teacher assessment method in their classroom.

\section{4. Instruments}

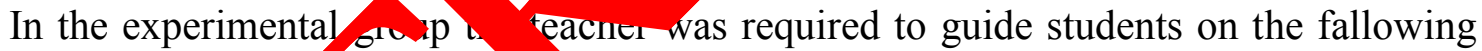
principles which are di ed from B nve2007:

- Tell stuo nts th rpose of the assessment: self assessment is a process that many stud cnts-especiah se in traditional educational system- will initially find quite $y$ comf able. They need to be sold on the concept. It is essential that instructor c. ${ }_{1} y$ ana zes the needs that will be met in offering self assessment opp nities and then convey this information to students.

Define tasks clearly: make sure the students know exactly what they are sumpose to do. If the instructor is offering a rating sheet or questioner, the task is mplex, but an open ended journal entry could leave students perplexed about what to write. Guidelines and models will be of great help in clarifying the procedure.

- Encourage impartial evaluation of performance or ability: one of the greatest drawbacks to self assessment is the threat of subjectivity. By showing students the advantage of honest, objective opinion, the teachers can maximize the beneficial washback of self assessment. Clear assessment criteria can go a long way toward encouraging objectivity.

- Ensure beneficial washback through fallow-up tasks: it is not enough to simply toss a self checklist at students and then walk away. Systematic follow-up can be 
accomplished through further self analysis, journal reflection, written feedback from the teacher, conferencing with the teacher, and purposeful goal setting.

\section{5. Procedure}

After the division of students into two groups, they were placed in their specific class and were trained under their specific instructions.

\section{5. 1 The Experimental Group (Self-Assessment Class)}

Prior to the start of the program a pretest was run in the first session. Aftery ard, from second session the teacher talked about the principles of self assessment in the inning of class. After that the teacher gave his instructions on different English Ess v W. Top like: punctuation, sentence formation, and different grammatical point were won in nis class. After the instructions of the teacher in those points, students in is cla vere aired to write an essay and use those points. In the following session whe the nack their writing into the class, they did the principles of self assessmer on their ays ad then the teacher gave some feedbacks on their writings. Table 1 is sh w the quest aire based on that students assessed themselves.

Table 1. Questionnaire of Sty ents' Self Assessm nt.

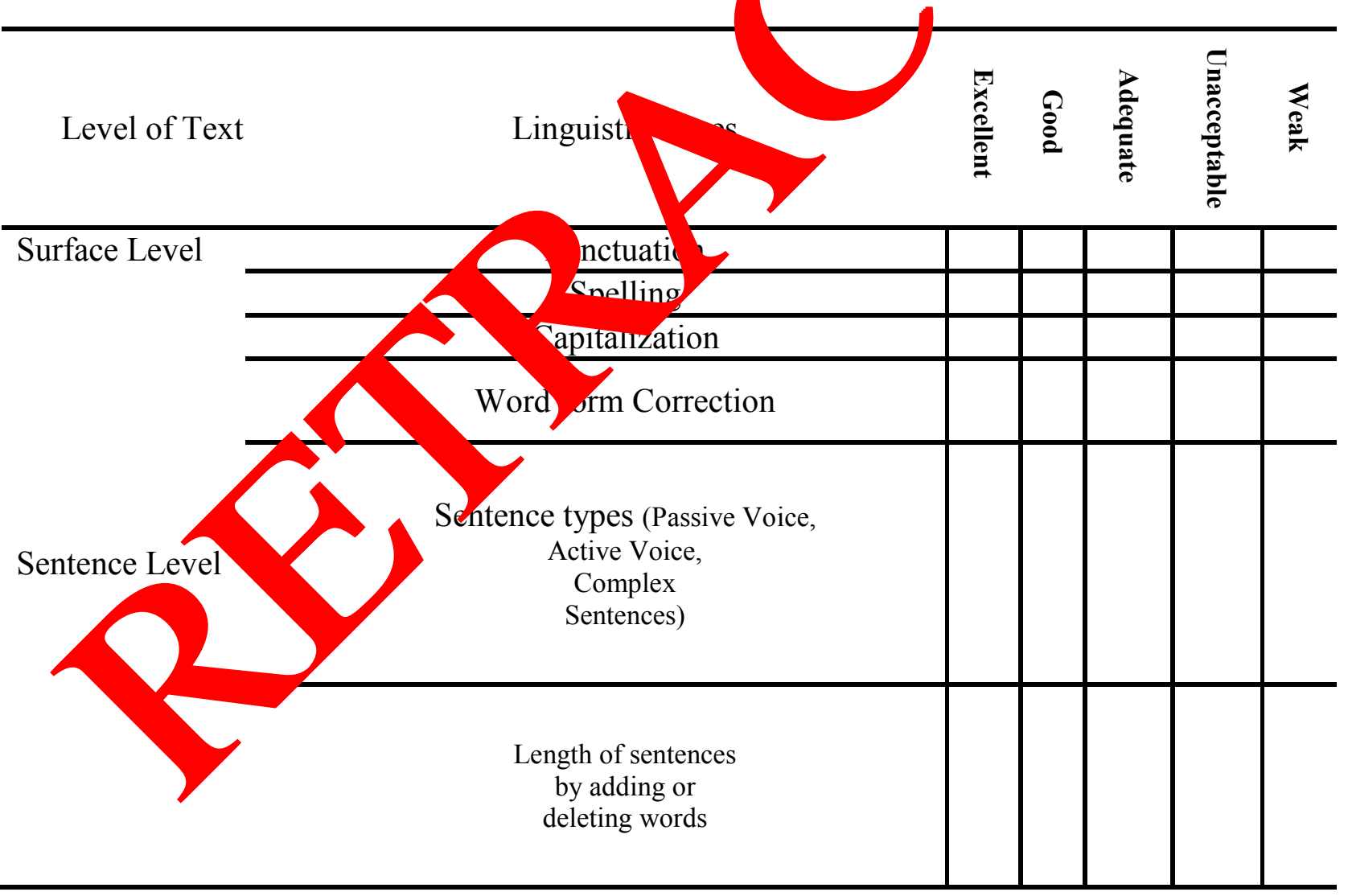

After students self assessed themselves, the teacher taught other English essay writing tips. In the final session the posttest was run and the pretest posttest design was completed. 


\section{5. 2 The Control Group (Teacher Assessment Class)}

Like EG class, in CG class there were two session of class each week for students. In the first Session of the program the pretest was held. Like the EG class each session the teacher prepared some tips and points of English essay writing. Students were required to write about a matter in regard to use the instructed points and tips. The following session when students came to the class with their essays the teacher did correction on their essays based on the traditional teacher assessment method.

The procedure was quite different from the EG class. Students delivered their essays to the teacher and he did the assessment and informed students on the results and al the needed feedbacks to the students. It should be stated that due to the time factor adents or I class had much more time in regarding to use teacher feedback in comparisen th EG cla In the final session the posttest was run.

\section{RESULTS}

The results of this investigation indicate some intere ing ints. Firs the descriptive statistics of both groups is illustrated in Table 2 then is a c ission on the research question and research hypothesis.

Table 2. Descriptive Statisti f EG and $C G$.

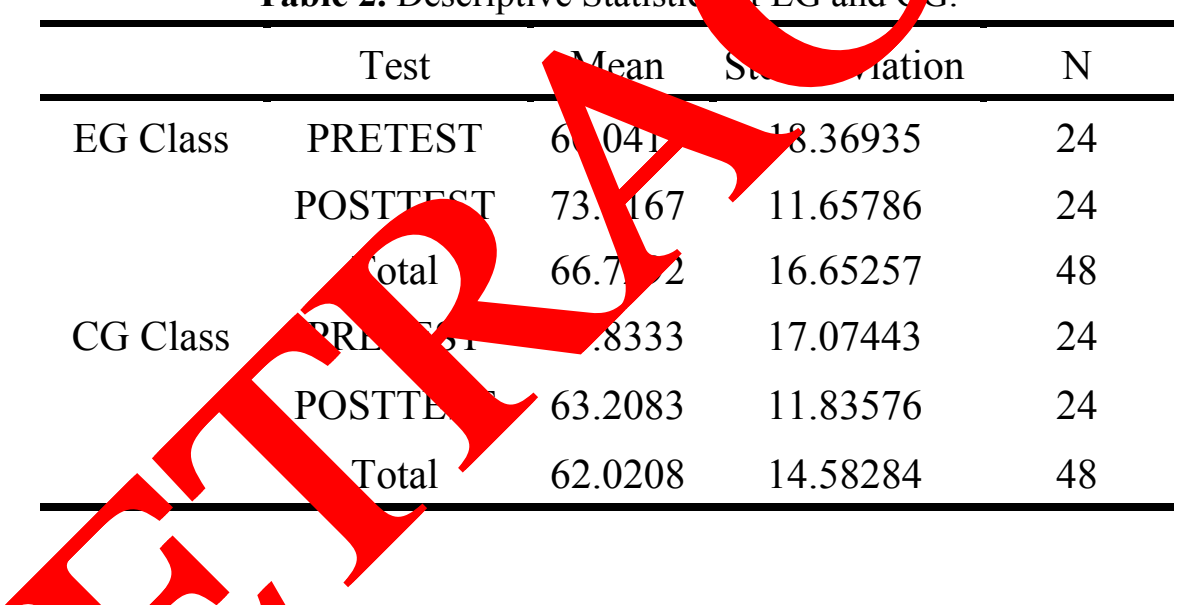

Table 2 a capa $\mathrm{e}$ in comparing the two groups. As one can see, in the pretest time the me core o b in groups-EG Class 60.04 and CG Class 60.83- are nearly the same that are a good co mation for the proficiency test that divided students into different pron no groups. But with the start in the program and placing students in the experi tal group whose assessment procedure was based on self assessment and the control group wh assessment procedure was based on teacher assessment one can see the way the means scove became different. In the posttest time the mean score of EG class was 73.41 that improved about 13.37 scores.

The mean score for CG class was 63.20 that improve only about 2.37. The comparison between the two groups means score- about 10.21- also show this fact that the improvement in the EG class is much more in the posttest time. In this investigation, for the purpose of clearer decision making on the research question and research hypothesis a Tests of Between-Subjects Effects was conducted. Table 3 is devoted to this data analysis. 
Table 3. Tests of Between-Subjects Effects.

\begin{tabular}{|cc|c|c|c|c|c|c|}
\hline Soure & Variable & $\begin{array}{c}\text { Type III Sum } \\
\text { of Squares }\end{array}$ & df & Mean Square & F & Sig. & $\begin{array}{c}\text { Partial Eta } \\
\text { Squared }\end{array}$ \\
\hline \multirow{2}{*}{ Test } & EG Class & 2146.688 & 1 & 2146.688 & 9.070 & .004 & .165 \\
& CG Class & 67.688 & 1 & 67.688 & .314 & .578 & .007 \\
\hline
\end{tabular}

a. $\mathrm{R}$ Squared $=.165($ Adjusted R Squared $=.147)$

b. R Squared $=.007$ (Adjusted R Squared $=-.015)$

The information obtained from Tests of Between-Subjects Effect is good on or rejection of the null hypothesis. The $p=.004$ in the EG class indica the setion null hypothesis and confirms that the implementation of self assessme thect of proving EFL learners writing ability. The answer to the research question is also po ve. T/e obtained information shows that self assessment improved Iranian $F$ oper inter ate students essay writing.

\section{CONCLUSION}

The results of the present study supparts the hyp nat the implementation of self assessment in the EFL writing classroom honificant effect on improving EFL English writing abilities, thus supporting the finding of investigations (Mills, Pajares, and Herron; 2006, 2007 and Noels et al; 2000, It was found that gains in knowledge and improvement of writing abilities ena o be lar erwith the implementation of self assessment in the writing classrooms. ve e counter, ne participants of the experimental groups demonstrate a mean score row 13.37 in a two month period program.

As a whole, the re ts are con ent with those of Hirvela \& Pierson (2000), who found that it is possible fo $\mathrm{Cz}$ rners to prove their writing abilities with implementing self assessment in writ 2000; Oscarsor, 1989) in tha adents who are using self assessment in regard with their writings ass ing ca improve their writing abilities. It is important to note that the learning condition and ext of present study is an EFL context so further researches may be require invest ES $L$ contexts. The participants of the study were in the upper immediate leve of pr ciency urther researches should investigate other level of proficiency in regard to $m p$ mantation of self assessment in writing classrooms.

stuay sheds light on the way that self assessment in the writing promotes students English $\quad y$ Writing, especially in the EFL upper intermediate context. If self assessment implement d in upper intermediate, and advanced level, students can gain knowledge in English Essay Writing. 


\section{References}

[1] Andrade, H. L. Boulay, B. A. (2003). Role of rubric-referenced self-assessment in learning to write. Journal of Educational Research, 97(1), 21-34.

[2] Andrade, H. L., Du, Y., Wang, X. (2008). Putting rubrics to the test: The effect of a model, criteria generation, and rubric-referenced self-assessment on elementary school students' writing. Educational Measurement, 27(2), 3-13. doi: $10.1111 / \mathrm{j} .1745-3992.2008 .00118$.

[3] Baer, A. L. (2008). Creating a shared definition of good and bad writing throug strategies. Middle School Journal, 39(4), 46-53.

[4] Bandura, A. (1977). Social learning theory. New York: General Learning Pr

[5] Beach, R. (1986). Demonstrating techniques for assessing writing ir the writing conference. College Composition and Communication, 37(1), 5

[6] Black, P., Wiliam, D. (1998). Inside the black box: Raising s anadra rough lassroom assessment. Phi Delta Kappa, 79, 139-48.

[7] Boud, D., Falchikov, N. (1989). Quantitative studies uden ${ }^{1}$-assessment in higher education: A critical analysis of findings. Higher Fucuion, 18(3, $29-549$.
doi: $10.3102 / 00346543059004395$

[8] Camp, H. (2012). The psychology of writing de lopment an its implications for assessment. Assessing Writing, 17(2), 92-105.

[9] Collins, V. T. (2000). Freewriting in the Self-help for college writers across the curriculum. In J.B. Smith \& K.B. Yance) (Ed cent self-assessment and development in writing: A collahorative in airy. ( $\$$ p. 105-124). Cresskill, NJ: Hampton Press.

[10] Dochy, F., Segers, M. S1t. na in higher education. Arviel Studies in Higher Education, 24(3), 331-350. doi: 10.1080/030 r9912331 az5

[11] Falchikov, N bud, 1989). Student self-assessment in higher education: A metaanalysis. Pevrew of Educ Yal Research, 59(4), 395-430. doi:10? 02/00 16543059004395

[13] Flower, L Hayes . R., Carey, L., Schriver, K., Stratman, J. (1986). Detection, sis, a he rategies of revision. College Composition and Communication, 37(1) 16-55.

[14] 1). Self-reflection and learner competence. Carleton Papers in Applied La age Studies, 8, 22-34.

[15] Harri,, K. R., Graham, S., Mason, L. H., Friedlander, B. (2008). Powerful writing strategies for all students. Baltimore, MD: Brookes.

[16] Jonsson, A., Svingby, G. (2007). The use of scoring rubrics: Reliability, validity and educational consequences. Educational Research Review, 2, 130-144. doi: 10.1016/j.edurev.2007.05.002

[17] Longhurst, N., Norton, L. S. (1997). Self-assessment in coursework essays. Studies in Educational Evaluation, 23, 319-330. 
[18] McCarthy, P., Meier, S., Rinderer, R. (1985). Self-efficacy and writing: A different view of self-evaluation. College Composition and Communication, 36, 465-471.

[19] Oldi eld, K. A., Macalpine, J. M. K. (1995). Peer and self-assessment at the tertiary level: An experiential report. Assessment and Evaluation in Higher Education, 20(1), 125-132.

[20] Ross, J. A., Rolheiser, C., Hogaboam-Gray, A. (1999). Effects of self-evaluation training on narrative writing. Assessing Writing, 6(1), 107-132. doi: 10.1016/S1075-2935(99)00003-3

[21] Monirosadat Hosseini, Mohamad Ehsan Taghizadeh, Mohamad Jafre Zain Abedin, Elham Naseri, (2013). In the Importance of EFL Learners' writing Skill ' here any Relation between Writing Skill and Content Score of English Essay T t? Im ration Letters of Social and Humanistic Sciences, 6, 1-12.

[22] Hussein Meihami, Bahram Meihami (2013). Correct I or I Dor a re Mys Corrective Feedback on EFL Students Writing. Internation rLetter SSocia and Humanistic Sciences, 7, 86-95.

[23] Hussein Meihami (2013). Truscott's Claims in Givino Jorred Feedback: Does It Matter in EFL Writing Context? International Le cers of Social
Sciences, 8, 8-23.

[24] Hussein Meihami (2013). Text-To-Speech Sof are: a New Perspective in Learning and Teaching Word Stress, Word Intonation, Pitch our, ar A Fluency of English Reading, International Letters of Soci Humarwa Sciences, 8 24-33.

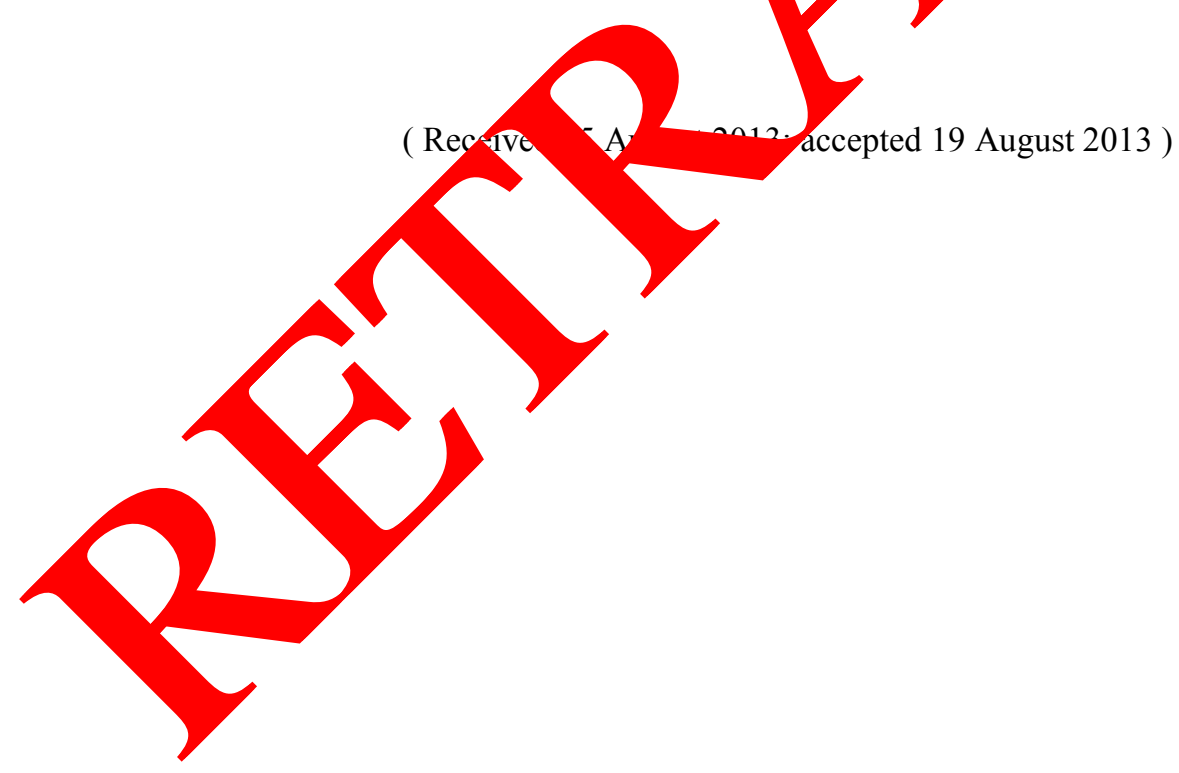

